\title{
Kultura codziennej nienawiści
}

Bardzo wiele publikacji z dziedziny nauk społecznych wskazuje na kryzys cywilizacyjny współczesnego świata. Dotyczy on zarówno tożsamości jednostek („błąd antropologiczny”), rozumienia rodziny, narodu, państwa, jak i braterskiego odczucia jedności ludzkości. Świat współczesny coraz częściej jawi się jako zlepek różnych problemów, tematów, zagadnień, zestawionych jak pogubione puzzle, niedopasowanych do siebie, tworzących zbiór przypadkowych skojarzeń i wydarzeń. $\mathrm{W}$ jednej z instalacji w muzeum sztuki współczesnej Albertinum w Dreźnie ułożono obok siebie wiele różnego rodzaju przedmioty codziennego użytku, tworząc z nich jeden regularny kwadrat. Telefon, czajnik, komputer, szczoteczka do zębów, suszarka - pieczołowicie spakowane i poukładane składają się na tę dziwną, nijak nieskoordynowaną całość. Instalacja przedstawia spakowany bałagan, poukładany chaos, który nie formuje się jednak w żaden ład i porządek, a opiera się jedynie na bliskiej obecności jednej rzeczy obok drugiej. Daje to pozór porządku i ładu, ale nie harmonii ${ }^{1}$.

\footnotetext{
1 Por. K. Pawlina, Deficyt człowieczeństwa, „Niedziela” 42 (2015), s. 29.
} 


\section{Etyka bałaganu i prymitywizmu}

Badacze wskazują na współczesny powrót człowieka pierwotnego, a nowoczesność postrzegają jako tryumf bałaganu, który odszedł daleko od porządku cywilizacyjnego. Współczesny człowiek pierwotny zatracił poczucie ładu, a posługuje się wyłącznie rytuałem. W fazie pierwszej oznacza on łamanie wszelkiego tabu, odrzucenie własnych zahamowań, uwolnienie najniższych pragnień i popędów. Mamy dziś do czynienia z erupcją wulgarności, agresji i seksualizacji oraz zaostrzającym się konfliktem społecznym. Faza druga polega na zakończeniu walki wszystkich ze wszystkimi przez rozpoczęcie walki wszystkich $\mathrm{z}$ naznaczonym przeciwnikiem, czyli znalezienie tzw. kozła ofiarnego. Atakuje się osoby, symbole, zakrzykuje racje i odrzuca jakiekolwiek argumenty, rozpalając wojnę kulturową 2 .

Najczęściej powtarzanym hasłem, zarówno w mediach, jak i w polityce, są wezwania: „bądź sobą!”, „słuchaj siebie”, „ufaj sobie”, idź swoja drogą”, przez co zatraca się społeczny wymiar życia ludzkiego, a skupia uwagę na jednostkowych odczuciach. Paul Vitz, amerykański psycholog, w książce Psychologia jako religia. Kult samouwielbienia wykazuje, że psychologia stała się humanistyczną religia opartą na kulcie „ja”. U jej podstaw leży filozofia, którą nazwał „selfizmem” (od ang. self - jaźń), który polega na kulcie samego siebie, na stawianiu na pierwszym miejscu narcystycznego „ego”3.

Istotnym atakiem jest przekreślenie znanych pojęć, znaczeń i treści odejście od znaczenia słów, które dotąd były zrozumiałe i dla wszystkich jednoznaczne ${ }^{4}$. Odebranie języka i manipulacja nim, narzucenie nowego znaczenia słów to pierwszy krok do uśmiercenia bliskości ludzi, którzy stają się niemi i bezradni wobec przetaczającej się obok nich debaty.

2 A. Grajewski, Powrót człowieka pierwotnego. Rozmowa z dr. Michałem Łuczewskim, dyrektorem Centrum Myśli Jana Pawła II w Warszawie, „Gość Niedzielny” 21 (2017), s. 20-21.

Por. T. Jaklewicz, Religia własnego „ja”, „Gość Niedzielny” 6 (2017), s. 22-24.

Por. G. Górny, Anioł Północy, Warszawa-Kraków 2010, s. 120-123. 


\section{Manipulacja językowa}

Według Arystotelesa „słowa są symbolicznymi znakami (symbola) wrażeń doznawanych w duszy, a dźwięki pisane są znakami dźwięków mówionych. Jako pisane, a także jako mówione, nie są dla wszystkich ludzi te same. Ale to, czego przede wszystkim są znakami (semia), wrażeń doznawanych w duszy, jest takie samo dla wszystkich, a więc i to, czego są te wrażenia podobiznami (homeiomata), mianowicie rzeczy, są również takie same"5.

Słowa są więc wynikiem konwencji, nie wynikają wprost z natury. Podlegają modom, zwyczajom, wpływom obcych kultur czy celowej deformacji. Mogą się zmieniać, chociaż prawda bytu, do którego się odnoszą, pozostaje taka sama. Nie zależy ona od nazywającego ją języka, gdyż nie jest efektem umowy ani dowolnie ustanowionych reguł. Podstawa prawdy znajduje się poza mową. Słowa najwyżej mniej lub gorzej ujmują jej sens ${ }^{6}$.

Pojęcia i słowa, którymi dysponujemy, są jedynie narzędziami do formułowania zdań, opisu rzeczywistości, wyrażania przypuszczeń i snucia różnych teorii. Pojęcia lub słowa nie mogą być ani prawdziwe, ani fałszywe. Służą jednak opisowi świata i językowi, w którym człowiek argumentuje swe racje ${ }^{7}$. Prawda jednak nie „mieszka” w słowach, lecz tam, dokąd słowa odsyłają: $\mathrm{w}$ realnym świecie, który jest dla nich odniesieniem ${ }^{8}$. Ta prawda, zasłaniania przez kłamców publicznych, wykorzystuje słowa do kreacji nowych prawd, które fałszywie wpisuje się w nowy, narzucany język. Nie zmienia on rzeczywistości, ale dla wielu staje się przeszkodą dla zrozumienia, czym jest prawda.

Termin „manipulacja” pochodzi od łac. manipulus, czyli „garść”. W łacinie średniowiecznej pojawił się czasownik manipulare w znaczeniu „robić coś rękami”. Dopiero w XIX wieku pojawiły się w językach europejskich określenia pochodzące od tego słowa dotyczące czynności umysłowych, a przy tym nieuczciwych. Obecnie określenie „manipulacja” oznacza „nieuczciwe posunięcia, machinacje”. W języku polskim to „poczynanie sobie

\footnotetext{
5 Arystoteles, Retoryka - poetyka, Warszawa 1988, za: B. Allen, Prawda w filozofii, Warszawa 1994, s. 23.

6 Por. A. Siemianowski, Człowiek i prawda, Poznań 1986, s. 29.

7 Por. K. R. Popper, W poszukiwaniu lepszego świata, tłum. A. Malinowski, Warszawa 1997, s. 210.

8 Por. M. Opoczyńska, Dialog innych albo inne monologi. Przypisy do psychoterapii, Kraków 2007, s. 16-20.
} 
z czymś nieuczciwie w celu zdobycia określonego wpływu na ludzi”, np. manipulacja danymi, historią, literaturą ${ }^{9}$.

Termin „manipulacja językowa” pozostaje jednak niejasny i nieprecyzyjny $^{10}$. W powszechnym przekonaniu łączy się z niejawnością, podstępem, nierzetelnym odbiorem informacji i doborem środków językowych, których celem jest umożliwienie kierowania zachowaniem ludzi, wywierania wpływu na ich nastroje, poglądy i opinie i osiąganie własnych korzyści. Jest to działanie etycznie potępiane, gdyż cele i korzyści, które chce osiągnąć nadawca, są obce odbiorcy, niezgodne z jego potrzebami, a nawet dla niego szkodliwe. Manipulowanie jest zawsze jakąś formą fałszywej relacji między ludźmi, a tym samym bardzo trudno je wykryć. Ukryte cele, które manipulacja zawiera, są możliwe do realizacji do chwili gdy nie zostaną odkryte i zdemaskowane ${ }^{11}$. Inną prawidłowością jest to, iż lęk przed siłą manipulacji i wyczulenie na nią ułatwia wpadnięcie w jej sidła. Sama bowiem wyobraźnia, np. dotycząca teorii spiskowych, sprzyja propagandzie, bo każe ją dostrzegać nawet tam, gdzie jej nie ma. Ktoś, kto zwraca uwagę na istniejącą manipulację, sam może być manipulatorem, który oczekuje od swych rozmówców oczekiwanych działań i zachowań ${ }^{12}$.

Zjawisko manipulacji jest niezwykle złożone. Łączy treści prawdziwe z fałszywymi, w jego ramach może mieścić się np. samokrytyka obozu rządzącego. Manipulacja nie przesadza w retuszowaniu świata rzeczywistego, by utrudnić identyfikację prawdy. Posługuje się słowami w sposób niezwykle elastyczny i dowolny, nie zwracając uwagi na ich znaczenie i skojarzenia, które wywołują, często pozostawiając margines domysłu i dowolnej twórczości odbiorcy ${ }^{13}$.

\footnotetext{
9 J. Puzynina, O pojęciu „manipulacji” oraz sensie wyrażenia „manipulacja językowa”, w: Nowomowa, bmw. i r., s. 7-21, Zeszyty Edukacji Narodowej. Dokumenty; zob. J. Puzynina, Język wartości, Warszawa 1992, s. 203-223.

10 Por. J. Bralczyk, Manipulacja językowa, w: Dziennikarstwo i świat mediów, red. Z. Bauer, E. Chudziński, Kraków 2000, s. 244-250.

11 J. Kwaśniewski, O manipulowaniu w życiu społecznym, w: Manipulacja i obrona przed manipulacją. Sesja na Uniwersytecie Warszawskim 1981, Warszawa 1981, s. 40-46; por. J. Kirschner, Manipulować - ale jak? Osiem praw postępowania z ludźmi, tłum. M. Auriga, Warszawa 1994.

12 M. Napiórkowski, Totalne teorie spiskowe, „Newsweek Polska Extra” 2 (2017), s. $120-125$.

13 Por. P. Pomerantsev, Putin na wojnie z Zachodem, „Newsweek Polska Extra” 2 (2017), s. $68-77$.
} 
Celem manipulacji słowem jest stworzenie świata iluzji, owładnięcie społeczeństwa kilkoma prostymi ideami. Jak twierdził jeden z teoretyków propagandy NSDAP: „należy je wmuszać w odbiorcę i wbijać mu do głowy w stu i więcej wariantach, z uporczywą konsekwencją"14. W nazistowskich Niemczech karano, nawet karą śmierci (od 1 września 1939 roku), słuchanie obcych rozgłośni. Hitler sugestywnie odwoływał się do najbardziej nośnych haseł, sentymentów, nadziei i lęków. Uruchomiono całą machinę propagandy i tworzenia ciepłego, rodzinnego wizerunku Wodza - według danych ministerstwa propagandy III Rzeszy w 1934 roku prywatne zdjęcie Führera było najchętniej kupowaną fotografią przez niemieckie i zagraniczne agencje prasowe. Radykalny antysemita i kierujący bojówkami wywrotowiec znany był jako miłośnik psów i górskich krajobrazów, przyjmujący u siebie małe dzieci i licznych mężów stanu. Uruchomiono kinematografię, z filmami tłumaczącymi sens walki, nadzieje Niemców i źródło antysemityzmu oraz wrogość wielu innych narodów Europy, które trzeba dyscyplinować w ich planach i zamiarach wobec Rzeszy ${ }^{15}$.

Od manipulacji słowem zaczyna się budowanie „nowego człowieka”. Dzisiaj narzędziem szerokiego wpływu na myślenie ludzi są media. Stwarzają one szeroką możliwość manipulacji, a przez to stają się skutecznym narzędziem politycznej dominacji jednych grup społecznych nad innymi. Dostęp do mediów oznacza ogromne możliwości wpływu, które mogą być wykorzystywane i celowo sterowane ${ }^{16}$.

W związku z masowością zjawiska manipulacji słowem 6 czerwca 1991 roku Jan Paweł II podczas wygłaszania homilii w Olsztynie poświęconej ósmemu przykazaniu Dekalogu - „Nie mów fałszywego świadectwa przeciw bliźniemu swemu” - wezwał do konsekwentnej „pracy nad mową”. Nawiązał do słów Cypriana Kamila Norwida o „wolności mowy”. Mówił:

14 Za: K. Lewicka, Jak się robi propagandę totalną. Rozmowa z prof. Eugeniuszem Cezarym Królem - historykiem i szefem Instytutu Studiów Politycznych PAN, „Newsweek Polska Extra” 2 (2017), s. 22-29; Por. M. Woźniak, Słowa w służbie zwycięstwa, „Tajemnice II wojny światowej. Super Album” 6 (2019), s. 84-85; M. Woźniak, Wojna na papierze, „Tajemnice II Wojny Światowej. Super Album” 6 (2019), s. 86-87.

15 Por. T. Targański, Kochał zwierzęta, uwielbiały go dzieci, „Newsweek Polska Extra” 2 (2017), s. 44-49; J. Szczerba, Perły propagandy filmowej, „Newsweek Polska Extra” 2 (2017), s. $30-43$.

16 M. Klobusicka, Możliwości manipulacji w mass mediach, w: Kłamstwo w życiu publicznym, red. W. Zuziak, J. Mysona Byrska, Kraków 2009, s. 123-130, Etyka i Życie Publiczne, 2. 
„Każdy podstęp wobec drugiego człowieka, każda skłonność do używania osoby ludzkiej w charakterze narzędzia, każde używanie słów po to, aby wpływać na innych swoim zagubieniem moralnym, swoim wewnętrznym nieporządkiem - wprowadza w życie społeczne atmosferę kłamstwa. (...) Przed czterema laty mówiłem, że czeka nas praca nad pracą. Dziś czeka nas wielka praca nad mową, jaką się posługujemy. Ogromna praca. Nasze słowo musi być wolne, musi wyrażać naszą wewnętrzną wolność. Nie można stosować środków przemocy, ażeby narzucać jakieś tezy. (...) Słowo ludzkie jest i powinno być narzędziem prawdy. (...) Wolność poza prawdą jest pozorem, a nawet zniewoleniem”17. Jan Paweł II podkreślił, że „wolność mowy” to także wolność od destrukcyjnego języka pogardy i nienawiści, od manipulacji i destrukcji znaczenia słów, których celem jest niszczenie drugiego człowieka ${ }^{18}$.

\section{Epoka postprawdy}

Wszelkie oznaki rozpadu kultury dają o sobie znać w języku jako podstawowym środku komunikacji współtworzącej kulturę. Trudno mówić o rozpadzie języka w stosunku do języków naturalnych. Dla językoznawców język zdolny do obsługiwania kultur i społeczeństw rozwija się i żyje, podlegając rozmaitym wpływom, również destrukcyjnym, wynikającym z terroru działań politycznych lub z kryzysu kultury bądź z kryzysu osobowości samych twórców ${ }^{19}$.

Zjawisko kryzysu słowa, a nawet rozpadu języka, we współczesnym świecie wiąże się z tzw. postprawdą. Sam termin pojawił się z początku lat 90. XX wieku. W artykule opublikowanym w czasopiśmie „The Nation” w roku 1992 Steve Resich stwierdził, że afera Irangate czy wojna w Zatoce Perskiej zostały łagodniej potraktowane niż słynna afera Watergate. Oceniając tę rzeczywistość, zwrócił uwagę, że to sami Amerykanie, „jako wolni ludzie dobrowolnie [zdecydowali], że chcemy żyć w świecie postprawdy”.

17 Jan Paweł II, Msza św. dla wiernych z diecezji warmińskiej, 6 czerwca 1991, w: Jan Paweł II, IV pielgrzymka do Ojczyzny, Kraków 1991, nr 5, s. 143-149.

18 Por. M. Rembierz, Niszczycielska moc słów, „Civitas Christiana” 1 (2017), s. 27.

19 W. Pianka, Nie ma rozpadu języka!, w: Rozpad mitu i języka?, red. B. Czapik, Katowice 1992, s. 184-192, Prace Naukowe Uniwersytetu Śląskiego w Katowicach, 1324. 
Nie mówił o kłamstwie, lecz o słabnącym znaczeniu prawdy, o powszechnej niechęci do konfrontowania swych poglądów z rzeczywistością. W takim też znaczeniu termin ten pojawiał się później w różnych publikacjach, które wskazywały na pewną strategię rządzenia polegającą na unikaniu nazywania rzeczy po imieniu, schodzeniu prawdzie z drogi. Te praktyki zebrał i oceniał w 2004 roku Ralph Keyes w książce The Post-Truth Era: Dishonesty and Deception in Contemporary Life. Autor nie mówił wyłącznie o politykach, ale zbierał wiele przykładów z życia publicznego, które wskazywały na rozszerzanie się zjawiska mijania się z prawdą i tendencji do kłamania jako stałej praktyce zachowań społecznych. Wytwarzały one nową jakość. Wyznaczały je dwuznaczne wypowiedzi, niebędące ścisłą prawdą, które sytuowały się obok kłamstwa, nie będąc nim jednak. Proponowano je nazwać „ulepszoną prawdą” (Keyes), „neoprawdą”, „miękką prawdą”, „fałszywą prawdą”, „prawdą dietetyczną”, "prawdą lajt”. Miała ona ogromne znaczenie społeczne, gdyż pozwalała uniknąć powiedzenia „twardej prawdy”, np. o tym, że globalny kapitalizm wytwarza więcej chaosu niż porządku, że pogłębia nierówności, zamiast je znosić, napędza eksploatację planety; prowadzi do katastrofy ekologicznej; a państwa coraz mniej panują nad jego dynamiką". W rezultacie niemówienia prawdy powstało szereg jej zastępników, a granica oddzielająca prawdę od fałszu ulegała coraz większemu zatarciu. Wzniesiono gmach zbudowany z języka powstałego z obaw i lęków, czyniąc prawdę jej ofiarą. Zatracono granicę między uczciwością i nieuczciwością. A to prowadziło, jak stwierdził Keyes: do „zagubienia piętna, jakim wcześniej obarczano kłamstwo (...). Kłamstwo stało się w zasadzie wykroczeniem, za które nie sposób kogokolwiek obwiniać"20.

Redakcja słownika oksfordzkiego uznała termin „postprawda” za słowo roku 2016. Jest ono pochodną zarówno manipulacji, świadomych i nieświadomych półprawd, jak i przekłamań i kłamstw, które funkcjonują w świadomości współczesnego człowieka oraz w subiektywistycznych postawach, które powtarzają, że „każdy ma swoją prawdę”. Gdy polski publicysta, Bronisław Wildstein, pisał o postprawdzie, odwołał się do opisu Friedricha Wilhelma Nietzschego: „Prawda to ruchliwa armia metafor, metonimii,

20 Zob. P. Czapliński, Niecała prawda o post-prawdzie, „Niezbędnik Inteligenta. Polityka” 1 (2017), s. 12-14; L. Sosnowski, Narodowe fałszowanie rzeczywistości, „Biały Kruk. Miesięcznik Kulturalny” 1 (2019), s. 5-8; J. Scahill, Brudne wojny, tłum. J. Małecki, Kraków 2014. 
antropomorfizmów, które po długim używaniu wydają się ludowi kanoniczne i obowiązujące. Prawdy są złudami, o których zapomniano, że nimi są, metaforami, które się zużyły i utraciły zmysłową siłę wyrazu"21.

Termin „postprawda” wykorzystuje prestiż sztandarowego pojęcia filozofii, jaką jest „prawda”. Dodano do niego odpowiedni przedrostek („post-), który ma wskazywać na nową jakość i nowatorskie ujęcie znanego pojęcia. „Postprawda” funkcjonuje w obrębie zamkniętego obiegu informacji, w których jawne kłamstwa funkcjonują obok informacji zmanipulowanych i prawdziwych. Wszystkie razem uzupełniają się, wzmacniają i potwierdzają. Do takich zamkniętych obiegów (tzw. „baniek medialnych”) nie dopływają informacje z zewnątrz, a czytelnicy czy słuchacze do ich zrozumienia i interpretacji wykorzystują głównie wiedzę potoczną i to, co uważają za opinię większości. Postprawda uzyskuje więc jedynie i wyłącznie „społeczny dowód prawdy” (coś jest prawdziwe, bo większość lub wszyscy tak uważają), nie umożliwiając jakąkolwiek polemikę czy dyskusję zmierzającą do poznania prawdy. Powstają w ten sposób wzmacniające się i potwierdzające wzajemnie ciągi kłamstwa. Postprawda więc to rodzaj kłamstwa, które wynika z wzajemnego wzmacniania się informacji prawdziwych, półprawd i kłamstw zamkniętych w medialnych systemach („bańkach”) ${ }^{22}$. Ważniejsze od prawdy jest osobiste doświadczenie i subiektywne przekonanie. Jednostka pozbawiona jest wsparcia rozumu - świadomie pozbawia się ją rozróżnienia między tym, co znajduje potwierdzenie w faktach, a tym, co „się wydaje”. Fakty przekazuje się dodatkowo zawiłym, zrozumiałym dla niewielu językiem²3.

Postprawda wskazuje na to, że w przestrzeni społecznej nie ma już miejsca na jakąkolwiek obiektywną prawdę. Poddające się powszechnej weryfikowalności fakty są lekceważone, zastępowane przez tzw. narracje, budowane w oparciu o emocje i uprzedzenia, celowo potęgowane przez wspierające je media. W ten sposób odrzuca się jeden $\mathrm{z}$ fundamentów kultury europejskiej

21 Za: Z. Niemirski, On nie jest postprawdą, „Gość Niedzielny” 19 (2017), s. 15.

22 R. Cienmiek, Postprawda - niebezpieczne zjawisko. Rozmowa z prof. Małgorzatą Lisowską-Magdziarz, medioznawcą i semiotykiem z Uniwersytetu Jagiellońskiego, www.wiadomosci.onet.pl/tylko-w-onecie/postprawda-niebezpieczne-zjawisko/71h1bq5 (15.07.2020).

23 A. Znatkiewicz, Historia płynie ze Wschodu na Zachód. Rozmowa z Timothym Synderem, autorem książki O tyranii, „Forum” 16 (2017), s. 68-70; Por. T. Rowiński, Bękarty Dantego. Szkice o zanikaniu i odradzaniu się widzialnego chrześcijaństwa, Tyniec 2015, s. $184-189$. 
- poszukiwanie prawdy. Ani jej poszukiwania, ani strzeżenie dorobku poprzednich pokoleń, a tym bardziej tworzenie dziedzictwa godnego przekazu na przyszłość nie ma już racji bytu ${ }^{24}$.

Postprawda jest nazwana też „bronią matematycznego rażenia” (Cathy O’Neill - amerykańska blogerka i matematyczka). Podkreśla się przy tym powszechne stosowanie algorytmów, które dotyczą wielu ludzi, funkcjonują w oparciu o utajnione reguły, a mają destrukcyjne działanie. Algorytm analizujący aktywność użytkowników na portalach społecznościowych można napisać tak, by zaskakiwał, odpowiadał temu, co subiektywnie dana jednostka lubi, podawał w wątpliwość jej poglądy lub wspierał społeczny dyskurs. Powstaje w ten sposób dodatkowy ośrodek, który zarządza strumieniem informacji i steruje automatycznie serwisami informacyjnymi, nie poddaje się żadnej kontroli, mające przy tym ogromny wpływ na wielu ludzi. Niemożliwa jest w tym strumieniu ochrona przed fake newsami, oddzielenie propagandy od faktów, szukanie wiarygodnych źródeł w zalewających społeczeństwo potoku informacji. Postprawda staje się nowym obliczem propagandy XXI wieku ${ }^{25}$.

Niesprawdzone lub jawnie fałszywe informacje przedostają się do obiegu społecznego z różnych źródeł. A ponieważ sam przekaz argumentów i faktów „nie działa”, przekazy adresowane są do emocji odbiorców. I tak np. podczas debaty nad pozostaniem Wielkiej Brytanii w Unii Europejskiej głos zabrało dziesięciu ekonomistów - laureatów Nagrody Nobla. Komentarz, który był odpowiedzią na ich argumenty, sprowadzał się do stwierdzenia: „Ludzie w tym kraju mają dość ekspertów”. Ekonomistów zaś porównano do niemieckich naukowców, którzy byli posłuszni Hitlerowi. Podczas kampanii wyborczej w Stanach Zjednoczonych, jak obliczał portal BuzzFeed, dwadzieścia najbardziej poczytnych fałszywych wiadomości o wyborach prezydenckich udostępniono 8 milionów 700 tysięcy razy. Dla porównania:

24 Por. abp Marek Jędraszewski, Przeciwko postprawdzie, gender i robocie, który został uznany za człowieka. Wykład inaugurujacy Radę Konferencji Episkopatów Europejskich $w$ Barcelonie, 28 marca 2017, w: Kościół $i$ Wiara. Stary kontynent. Reportaż, www.swiato-podglad.pl/abp-marek-jedraszewski/abp-marek-jedraszewski-przeciwko-postprawdzie-gender-i-robocie-ktory-zostal-uznany-czlowiekiem (15.07.2020); abp Jędraszewski, Żyjemy w świecie post-prawdy, www.pch24.pl/abp-jedraszewski--zyjemy-w-swiecie-post-prawdy,50509,i. html (15.07.2020).

25 C. O’Neill, Broń matematycznego rażenia, „Süddeutsche Zeitung”, w: Internet, (14.12.2017). 
dwadzieścia prawdziwych doniesień miało 7 milionów 400 tysięcy udostępnień. W ten sposób fałsz zdominował fakty. Sam kandydat brnął w absurdy, co nie przeszkadzało w efektywności jego kampanii. Obliczono, że 70 proc. wypowiedzi przedwyborczych jednego z kandydatów w różnym stopniu mijało się z prawdą. Ale to wyborcy decydowali, które informacje są czytane, powtarzane i powielane. $\mathrm{W}$ ten sposób w rozbudowę postprawdy są zaangażowani wszyscy ${ }^{26}$.

Postprawda bazuje na rzeczywistości, którą myśliciele postmodernistyczni opisują jako simulacrum. Oznacza ono kopię bez oryginału. Współczesny świat jest pełen symulakrów, pustych znaków, pojęć i symboli, które nie odsyłają do żadnej rzeczywistości. Już dawno utraciły walor autentyczności, pozostając kopią dawnych znaczeń i pojęć ${ }^{27}$.

Działalność polityków, ze względu na zakres i siłę oddziaływania społecznego, ma bardzo duży udział w wytworzeniu się we współczesnej kulturze wymienionych przez papieża „obszarów kłamstwa”. Polityka jako umiejętność zyskiwania poklasku, utrzymywania stanowisk i poszerzania obszarów wpływu stanęła w opozycji do obiektywnej prawdy, która nie ma dla niej zbyt wielkiej wartości ${ }^{28}$.

Znany, nieżyjący już polski filozof Józef Maria Bochenski zwracał uwagę, że całe ludzkie poznanie trzeba pojmować albo jako ujmowanie, albo jako tworzenie przedmiotu. Gdy nie ma woli podjęcia wysiłku, by poznać dany przedmiot, to opisując go, tworzymy alternatywną rzeczywistość, coś podobnego do nieznanego $\mathrm{w}$ istocie przedmiotu ${ }^{29}$. Tworzy się wówczas świat nierozpoznanych przedmiotów. A ponieważ współcześnie tendencja do „tworzenia” wyraźnie dominuje nad trudem poznawania, powstał świat złożony z obcych w istocie części i elementów. Amerykański socjolog George Ritzer w pracy pt. Globalization of Nothing (pl. Globalizacja niczego) z 2006 roku, wskazuje, że człowiek współczesny „siedzi nigdzie, pije nic”. Różnica między „czymś” a „niczym” jest empiryczna, a nie aksjologiczna. Istotą globalizacji niczego jest wydajność, społeczna odmiana nowego rodzaju fordyzmu, który zamienił producentów z twórców na wykonawców,

26 M. Zimmerman, Po odrobinie postprawdy wszyscy mamy na rękach, www.wiadomosci.onet.pl/tylko-w-onecie/po-odrobinie-postprawdy-wszyscy-mamy-na-rekach/k8dv4gl (12 12 2017).

27 G. Gorny, Anioł Pótnocy, dz. cyt., s. 129-131.

28 Por. A. Zaorska, Twórcy nienawiści, „Warszawska Gazeta” 3 (2019), s. 28-31.

29 J. M. Bocheński, Ku filozoficznemu myśleniu, Warszawa 1986, s. 34. 
nieświadomych celu i sensu swej pracy. Podobnie proponowana konsumpcja niewiele ma wspólnego z zaspokajaniem potrzeb. Nie robi się zakupów, aby mieć się w co ubrać, tylko żeby coś kupić. Udziałem konsumenta jest „wieczne niezaspokojenie”. Podobnie dzieje się z innymi sferami życia społecznego: partie uprawiają „nie-politykę”; demokracja połączyła się z „nie-wybieraniem”; uczelnie coraz częściej są „nie-uniwersytetem”; wspólnoty religijne są często „nie-kościołami”; ludzie „nie-żyją”. Utrata istoty wielu pojęć stwarza świat obcy, tajemny, nienazwany. A język jest już za ubogi, aby ująć i opisać dokonujący się proces zaniku sensu i znaczenia wielu pojęćc ${ }^{30}$.

W związku z tym pojawiły się propozycje odrzucenia jakiejkolwiek „metanarracji”, w tym naukowej. Dokonuje się to pod hasłami uwolnienia człowieka od nieustannego poszukiwania prawdy, odrzucenia „zadufanego w sobie" realizmu, który domaga się bezzasadnie korespondowania z faktami. Do pierwszych zadań nauki powinna należeć wolność konwersacji, a nie szukanie prawdy. Nauka wówczas będzie mogła cieszyć się wolną, niczym nieskrępowaną grą własnych pomysłów. Celem ma być uwolnienie nauki od uwięzienia w dogmatach, gdyż „kto pragnie teorii poznania, ten pragnie przymusu"31.

\section{Epoka hejtu}

„Uwolniona” nauka nie ma już języka, którym mogłaby się komunikować. Kolejnymi faktami, będącymi elementami dowolnej jej gry, stwarza nowy świat. Jest to świat pozbawiony ducha, a budowany najczęściej na nienawiści. Świat elektronicznych przekaźników stał się przestrzenią stwarzaną przez tzw. „hejt” - pełen nienawiści, pogardy, złości, adresowany zarówno do konkretnej osoby, jak i do przedstawicieli danego narodu, płci, osób o innym światopoglądzie niż reprezentowany przez hejtera, wyznawców danej religii czy grupy politycznej.

30 Por. J. Żakowski, Siedzimy nigdzie, pijemy nic. Rozmowa z George’em Ritzerem, „Niezbędnik Inteligenta. „Polityka” 16 (2007), s. 3-8.

31 R. Rorty, Filozofia a zwierciadło natury, tłum. M. Szczubiałka, Warszawa 1994, s. 281; Por. J.-F. Lyotard, Kondycja ponowoczesna, tłum. M. Kowalska, J. Migasiński, Warszawa 1997. 
„Hejt” (ang. hate - „nienawiść") wyraża się w internecie nie tylko za pomocą słów, ale też grafiki (memów, gifów) czy filmów - by łatwiej zapadał w pamięć odbiorców. Przekazywane w ten sposób treści nie mają żadnej wartości merytorycznej. To treści ukierunkowana wyłącznie przeciwko danej osobie lub grupie osób ${ }^{32}$.

Hejter (z ang. hater- „nienawistnik, przeciwnik, krytykant”) to określona osoba, która poświęca swój czas i zaangażowanie dla publikacji w internecie - najczęściej pod pseudonimem - agresywnych, obraźliwych i skrajnie krytycznych komentarzy. Te wystąpienia są postrzegane jako akty cyberprzemocy i psychicznego nękania (stalking). Często występuje w nich mowa nienawiści - adresowana najczęściej do osób publicznych ${ }^{33}$.

Polskie badania w 2017 roku - wywiady z grupą 6 i pół tysiąca internautów) - wykazały, że hejter w Polsce to mężczyzna (stanowią 53 proc. hejterów) w wieku od 16. do 24 . roku życia (aż 73 proc. hejtujących), który ma wykształcenie średnie ogólnokształcące (35 proc.). Co piąty ma wykształcenie wyższe. Publikuje swe negatywne posty kilka razy w tygodniu ${ }^{34}$.

Psychologiczna analiza przyczyn hejtowania pozwalają sformułować tezy, że hejtowanie przynosi ulgę (badania w Szwajcarii pokazały, że oszukani w grze ekonomicznej w hejcie szukali uczucia ulgi, siły, poczucia sprawiedliwości); jest instrumentem pozwalającym każdemu podjąć czynienie zła (upowszechnia możliwość zemsty); zapewnia anonimowość i pośredniość, a tym samym bezkarność; daje upust stereotypom i uprzedzeniom; niekiedy jest możliwą formą okazania zazdrości i niezadowolenia ${ }^{35}$.

Współczesny człowiek jest pełen nienawiści, a jeszcze częściej lęku $i$ buntu. $U$ podstaw jego nienawiści jest odmowa zaakceptowania siebie jako stworzenia, brak perspektywy teologicznej dla swego życia. Papież Benedykt XVI 20 lutego 2009 roku wyraził tę prawdę słowami: „Człowiek nie jest absolutem, tak jakby «ja» mogło się oddzielić i postępować jedynie według

32 Zob. A. Sierant, Hejt, czyli o mowie nienawiści w internecie. Przyczyny i konsekwencje hejtu, w: www.poradnikzdrowie.pl/psychologia/emocje/hejt-czyli-o-mowie-nienawisci-w-internecie (31.03.2020).

33 Hejter, w: www.dobryslownik.pl/slowo/hejter/218709/\#znaczenie-203108 (27.08.2019).

34 Raport Centrum Badań nad Uprzedzeniami we współpracy z Fundacja im. Stefana Batorego nt. zjawisk przemocy werbalnej wobec przedstawicieli grup mniejszościowych, www.rpo.gov.pl/sites/default/files (31.03.2020).

35 http://www.centrumprasowe.swps.pl (31.03.2020); por. M. Osiak, Kiedy krytyka zamienia się w hejt?, www.marcinosiak.pl/kiedy-krytyka-zamienia-sie-hejt (31.03.2020). 
własnej woli. Jest to sprzeczne z prawdą o naszym jestestwie. Prawdą o nas jest przede wszystkim to, że jesteśmy stworzeniami, Bożymi stworzeniami, i żyjemy w relacji ze Stwórcą. Jesteśmy istotami stworzonymi do relacji. I tylko akceptując tę naszą relacyjność, dochodzimy do prawdy, w przeciwnym razie popadamy w zakłamanie, a zatem jesteśmy zależni od Stwórcy. (...) Być stworzeniem oznacza być kochanym przez Stwórcę, pozostawać w relacji miłości, którą nas obdarza, która nas uprzedza"36.

\section{Bibliografia}

Allen B., Prawda w filozofii, Warszawa 1994.

Benedykt XVI, Do alumnów Rzymskiego Wyższego Seminarium Duchownego, „L'Osservatore Romano”, wyd. polskie 4 (2009), s. 28-29.

Bocheński J. M., Ku filozoficznemu myśleniu, Warszawa 1986.

Bralczyk J., Manipulacja jezzykowa, w: Dziennikarstwo i świat mediów, red. Z. Bauer, E. Chudziński, Kraków 2000, s. 244-250.

Cienmiek R., Postprawda - niebezpieczne zjawisko. Rozmowa z prof. Małgorzatą Lisowską-Magdziarz, medioznawcą i semiotykiem z Uniwersytetu Jagiellońskiego, www.wiadomosci.onet.pl/tylko-w-onecie/postprawda-niebezpieczne-zjawisko/71h1bq5 (15.07.2020).

Czapliński P., Niecała prawda o post-prawdzie, „Niezbędnik Inteligenta. Polityka" 1 (2017), s. 12-14.

Górny G., Anioł Północy, Warszawa-Kraków 2001.

Grajewski A., Powrót człowieka pierwotnego. Rozmowa z dr. Michałem Łuczewskim, dyrektorem Centrum Myśli Jana Pawła II w Warszawie, „Gość Niedzielny” 21 (2017), s. 20-21.

Jaklewicz T., Religia własnego „ja”, „Gość Niedzielny” 6 (2017), s. 22-24.

Jan Paweł II, Msza św. dla wiernych z diecezji warmińskiej, 6 czerwca 1991, w: Jan Paweł II, Pielgrzymki do Ojczyzny 1979, 1983, 1987, 1991, 1995, 1997, 1999, 2002. Przemówienia, homilie, Kraków 2005, s. 143-149.

Jędraszewski M., Przeciwko postprawdzie, gender i robocie, który został uznany za człowieka. Wykład inaugurujący Radę Konferencji Episkopa-

36 Benedykt XVI, Do alumnów Rzymskiego Wyższego Seminarium Duchownego, „L'Osservatore Romano”, wyd. polskie, (2009) nr 4, s. 28-29. 
tów Europejskich w Barcelonie, 28 marca 2017, w: Kościół i Wiara. Stary kontynent. Reportaż, www.swiato-podglad.pl/abp-marek-jedraszewski/ abp-marek-jedraszewski-przeciwko-postprawdzie-gender-i-robocie-ktory-zostal-uznany-czlowiekiem (15.07.2020).

Kirschner J., Manipulować - ale jak? Osiem praw postępowania z ludźmi, tłum. M. Auriga, Warszawa 1994.

Klobusicka M., Możliwości manipulacji $w$ mass mediach, w: Kłamstwo w życiu publicznym, red. W. Zuziak, J. Mysona Byrska, Kraków 2009, s. 123130, Etyka i Życie Publiczne, 2.

Kwaśniewski J., O manipulowaniu w życiu społecznym, w: Manipulacja i obrona przed manipulacja. Sesja na Uniwersytecie Warszawskim 1981, Warszawa 1981, s. 40-46.

Lewicka K., Jak się robi propagandę totalną. Rozmowa z prof. Eugeniuszem Cezarym Królem - historykiem i szefem Instytutu Studiów Politycznych PAN, „Newsweek Polska Extra” 2 (2017), s. 22-29.

Lyotard J.-F., Kondycja ponowoczesna, tłum. M. Kowalska, J. Migasiński, Warszawa 1997.

Napiórkowski M., Totalne teorie spiskowe, „Newsweek Polska Extra” 2 (2017), s. 120-125.

Niemirski Z., On nie jest postprawdą, „Gość Niedzielny” 19 (2017), s. 15.

O’Neill C., Broń matematycznego rażenia, „Süddeutsche Zeitung”, w: Internet, dostęp: 14.12.2017.

Opoczyńska M., Dialog innych albo inne monologi. Przypisy do psychoterapii, Kraków 2007.

Osiak M., Kiedy krytyka zamienia się w hejt?, www.marcinosiak.pl/kiedy-krytyka-zamienia-sie-hejt (31.03.2020).

Pawlina K., Deficyt człowieczeństwa, „Niedziela” 42 (2015), s. 29.

Pianka W., Nie ma rozpadu języka!, w: Rozpad mitu i jezzyka?, red. B. Czapik, Katowice 1992, s. 184-192, Prace Naukowe Uniwersytetu Śląskiego w Katowicach, 1324,

Pomerantsev P., Putin na wojnie z Zachodem, „Newsweek Polska Extra” 2 (2017), s. 68-77.

Popper K. R., W poszukiwaniu lepszego świata, tłum. A. Malinowski, Warszawa 1997. 
Puzynina J., O pojęciu „manipulacji” oraz sensie wyrażenia „manipulacja jezykowa", w: Nowomowa, bmw. i r., Zeszyty Edukacji Narodowej. Dokumenty.

Raport Centrum Badań nad Uprzedzeniami we współpracy z Fundacja im. Stefana Batorego nt. zjawisk przemocy werbalnej wobec przedstawicieli grup mniejszościowych, ww.rpo.gov.pl/sites/default/files (31.03.2020).

Rembierz M., Niszczycielska moc słów, „Civitas Christiana” 1 (2017), s. 27.

Rorty R., Filozofia a zwierciadło natury, tłum. M. Szczubiałka, Warszawa 1994.

Rowiński T., Bękarty Dantego. Szkice o zanikaniu i odradzaniu się widzialnego chrześcijaństwa, Tyniec 2015.

Scahill J., Brudne wojny, tłum. J. Małecki, Kraków 2014.

Siemianowski A., Człowiek i prawda, Poznań 1986.

Sierant A., Hejt, czyli o mowie nienawiści w internecie. Przyczyny i konsekwencje hejtu, www.poradnikzdrowie.pl/psychologia/emocje/hejt-czyli-o-mowie-nienawisci-w-internecie (31.03.2020).

Sosnowski L., Narodowe fałszowanie rzeczywistości, „Biały Kruk. Miesięcznik Kulturalny" 1 (2019), s. 5-8.

Szczerba J., Perły propagandy filmowej, „Newsweek Polska Extra” 2 (2017), s. $30-43$.

Targański T., Kochał zwierzęta, uwielbiały go dzieci, „Newsweek Polska Extra” 2 (2017), s. 44-49.

Woźniak M., Słowa w służbie zwycięstwa, „Tajemnice II wojny światowej. Super Album" 6 (2019), s. 84-85.

Woźniak M., Wojna na papierze, „Tajemnice II Wojny Światowej. Super Album" 6 (2019), s. 86-87.

Zaorska A., Twórcy nienawiści, „Warszawska Gazeta” 3 (2019), s. 28-31.

Zimmerman M., Po odrobinie postprawdy wszyscy mamy na rękach, www. wiadomosci.onet.pl/tylko-w-onecie/po-odrobinie-postprawdy-wszyscy-mamy-na-rekach/k8dv4gl (12.12.2017).

Znatkiewicz A., Historia płynie ze Wschodu na Zachód. Rozmowa z Timothym Synderem, autorem książki O tyranii, „Forum” 16 (2017), s. $68-70$.

Żakowski J., Siedzimy nigdzie, pijemy nic. Rozmowa z George'em Ritzerem, „Niezbędnik Inteligenta. Polityka” 16 (2007), s. 3-8. 
